Note

\title{
DEVELOPMENT OF Colletotrichum gloeosporioides ISOLATED FROM GREEN PEPPER IN DIFFERENT CULTURE MEDIA, TEMPERATURES, AND LIGHT REGIMES
}

\author{
Alexandre Furtado Silveira Mello후 Andressa Cristina Zamboni Machado ${ }^{1}$; Ivan Paulo Bedendo* \\ ${ }_{2}^{1} U S P / E S A L Q$ - Programa de Pós-Graduação em Fitopatologia. \\ ${ }^{2}$ USP/ESALQ - Depto. de Entomologia, Fitopatologia e Zoologia Agrícola, C.P. 09 - 13418-900 - Piracicaba, SP - \\ Brasil. \\ *Corresponding author <ipbedend@esalq.usp.br>
}

\begin{abstract}
Control of anthracnose in green pepper involves the use of resistant varieties and/or fungicides. The selection of varieties and efficient products demands great amounts of conidia as inoculum. It is thus necessary to optimize the production of Colletotrichum gloeosporioides conidia in the laboratory, establishing the best conditions for fungus development. The present study aimed at determining the most favorable culture media, temperature, and light conditions for the production of fungus inoculum. The fungus was isolated from green pepper fruits (Capsicum annuum L.) and transferred to four culture media (PDA, oat, filtered pepper extract, and autoclaved pepper extract), under different temperatures $(15,20,25,30$, and $35^{\circ} \mathrm{C}$ ) and light conditions (24h dark, and 24h light). Colony growth was evaluated after 7 and 12 days of incubation. No differences were found between the culture media. However, the greatest number of conidia was obtained from colonies grown in oat medium at $25^{\circ} \mathrm{C}$. Temperatures of 20 and $25^{\circ} \mathrm{C}$ were the most favorable for colony growth and sporulation. Higher sporulation was obtained under incubation in constant light. Cultivation of C. gloeosporioides in oat medium, at $25^{\circ} \mathrm{C}$, and constant light is recommended.
\end{abstract}

Key words: Capsicum annuum, anthracnose, mycelium growth, sporulation

\section{DESENVOLVIMENTO DE Colletotrichum gloeosporioides ISOLADO DE PIMENTÃO EM DIFERENTES MEIOS DE CULTURA, TEMPERATURAS E REGIMES DE LUZ}

\begin{abstract}
RESUMO: O controle da antracnose causada por Colletotrichum gloeosporioides em pimentão, envolve o emprego de variedades resistentes e/ou fungicidas. A seleção de variedades e de produtos eficientes demanda grande quantidade de inóculo. Assim, é necessário otimizar a produção de conídios em laboratório, estabelecendo as melhores condições para tal. O presente trabalho teve por objetivo determinar o meio de cultura, a temperatura e o regime de luz mais favoráveis à produção de inóculo do fungo. O isolado fúngico foi obtido de frutos de pimentão e cultivado em quatro meios de cultura (BDA, aveia, extrato de pimentão filtrado e extrato de pimentão autoclavado), sob diferentes temperaturas $\left(15,20,25\right.$, 30 e $\left.35^{\circ} \mathrm{C}\right)$ e regimes de luz ( $24 \mathrm{~h}$ de escuro, $24 \mathrm{~h}$ de luz). O crescimento da colônia foi avaliado aos 7 e 12 dias, não sendo observadas diferenças entre os meios, aos 12 dias após a incubação. Entretanto, maior produção de conídios foi obtida de colônias crescidas em aveia a $25^{\circ} \mathrm{C}$. As temperaturas de 20 e $25^{\circ} \mathrm{C}$ foram as mais favoráveis para o crescimento da colônia e para esporulação do fungo. A produção de conídios foi maior quando em incubação sob luz contínua diferindo da incubação sob escuro total, aos 12 dias. Para obtenção de inóculo, indica-se o cultivo de C. gloeosporioides em meio de aveia, a $25^{\circ} \mathrm{C}$, sob luz contínua, por 12 dias.

Palavras-chave: Capsicum annuum, antracnose, crescimento micelial, esporulação
\end{abstract}

\section{INTRODUCTION}

Anthracnose, a disease caused by Colletotrichum gloeosporioides (Penz) Penz \& Sacc., produces depressed circular spots in green pepper fruits, and under conditions of mild to hot climate, high moisture, and a large amount of inoculum, it can cause relevant yield losses (Kurozawa \& Pavan, 1997). Control can be done by using resistant varieties or through the application of chemical products.
Inoculum availability must exist if the resistance of plant materials and the efficiency of products are to be evaluated. To achieve inoculum mass production, it is therefore important to determine suitable culture media and favorable physical conditions for spore production by the fungus.

The potato-dextrose-agar (PDA) and oat media have been routinely used for phytopathogenic fungi growth and sporulation. Notwithstanding, medium com- 
position, especially the use of different plant material, and factors such as temperature and light, have allowed increased production of spores (Dalla Pria et al., 1997).

The objective of this work was to evaluate the effect of the composition of some culture media, temperatures, and light regimes on mycelial growth and conidia production of $C$. gloeosporioides, aimed at determining conditions that favor development and inoculum production for conducting future assays that would require artificial mass inoculation.

\section{MATERIAL AND METHODS}

A C. gloeosporioides isolate, obtained by direct isolation in agar-water from green pepper fruits showing typical anthracnose symptoms, collected in a producing field in the Jarinú-SP region ( $23^{\circ} 06^{\prime} 05^{\prime \prime}$ 'S; $46^{\circ} 43^{\prime} 42^{\prime \prime} \mathrm{W}$ ) was used. After incubation for three days at $20^{\circ} \mathrm{C}$ and under continuous light, the fungus was transferred to tubes containing PDA and maintained in refrigerator at $25^{\circ} \mathrm{C}$.

Evaluation of fungus mycelial growth and sporulation in different culture media was performed using PDA (200 g baked potatoes, $20 \mathrm{~g}$ dextrose, and $15 \mathrm{~g}$ agar), oat (40 g flour, $15 \mathrm{~g}$ agar, and 1,000 $\mathrm{mL}$ water), and green pepper. The last medium was prepared with autoclaved and non-autoclaved fruit broth obtained by boiling $200 \mathrm{~g}$ of chopped, green fruits in $500 \mathrm{~mL}$ of distilled water; broth was then filtered through a sieve, added of $10 \mathrm{~g}$ dextrose and $7.5 \mathrm{~g}$ agar, and autoclaved. For the non-autoclaved broth, the same amount of green pepper was boiled in $300 \mathrm{~mL}$ of distilled water, and the broth was passed through a sieve and sterilized through a filtering membrane $(0.22 \mu \mathrm{m})$. The sterilized broth was mixed with $200 \mathrm{~mL}$ of distilled water added of $10 \mathrm{~g}$ autoclaved dextrose and $7.5 \mathrm{~g}$ autoclaved agar. Mycelium discs with a $0.5 \mathrm{~cm}$ diameter were transferred to the center of the plates containing each media. The incubation of colonies was performed at $28^{\circ} \mathrm{C}$ under continuous light.

The effect of incubation temperatures on mycelial growth and on conidia production at 15, 20, 25, 30, and $35^{\circ} \mathrm{C}$ was evaluated. In this case, mycelium discs $(0.5 \mathrm{~cm})$ were transferred to the center of plates containing PDA, and incubation was conducted under continuous light in BOD incubators.

The effect of light regimes on sporulation was evaluated by incubating the fungus colonies under continuous dark and continuous light conditions. Fluorescent 250 lux bulbs were used when the fungus was exposed to light. Mycelium discs $(0.5 \mathrm{~cm})$ were transferred to the center of plates containing PDA medium, and incubation was done at a temperature of $25^{\circ} \mathrm{C}$.

Mycelial growth was evaluated at $7^{\text {th }}$ and $12^{\text {th }}$ day; the diameter of colonies was measured along two transversely-oriented axes. Spore production was quantified at seven and 12 days after plating, using a hemocytometer. The volumes of the conidia-bearing suspension used for counting was 10 and $20 \mathrm{~mL}$, for evaluations on days seven and 12 days, respectively. A completely randomized experimental design was used, with six replicates for mycelial growth (one plate per replicate) and 48 replicates for spore production (8 readings per plate). Data on culture media and lighting condition were submitted to statistical analysis; means were compared by Tukey test $(\alpha=0.05)$. For the temperatures assay, the evaluated variables (mycelial growth and number of conidia produced) were submitted to regression analysis using the same statistical software, aiming to calculate the equation that would provide the best data fit, using polynomial regression.

\section{RESULTS AND DISCUSSION}

Mycelial growth, evaluated on day seven, did not show differences among the four media: PDA $6.43 \mathrm{~cm}$, oat $6.60 \mathrm{~cm}$, autoclaved green pepper $6.17 \mathrm{~cm}$ and filtered green pepper $5.77 \mathrm{~cm}$. This demonstrated that the host extract media did not promote increased mycelial growth.

A quadratic model best explained the negative impact resulting from temperature increase on the analyzed variables (mycelial growth and production of conidia). The incubation temperature affected on mycelial growth $(P<0.05)$; 20 and $25^{\circ} \mathrm{C}$ were the most favorable temperatures, both on days seven and 12 (Figure 1-A); the following equations were obtained:

$$
\begin{aligned}
& Y=-0.020 X^{2}+0.891 X-5.574 \quad R^{2}=0.87 \text { (7 days) } \\
& Y=-0.036 X^{2}+1.637 X-12.761 \quad R^{2}=0.77 \quad(12 \text { days) }
\end{aligned}
$$

where $\mathrm{Y}$ is mycelial growth and $\mathrm{X}$ is incubation temperature.

The observation that milder temperatures are more adequate for this genus of fungus was also verified in a similar research (Dalla Pria et al., 1997). These results also agree with reports showing that the disease caused by Colletotrichum spp. is detrimental under milder temperature conditions (King et al., 1997; Kurozawa \& Pavan, 1997).

With regard to sporulation, the culture media composition showed differences (Table 1). In 7- and 12day old colonies, sporulation in oat and PDA was higher than in green pepper media. Four to five times more spores were obtained in the oat medium than in the media prepared with host tissue. The production of conidia in PDA represented about $40 \%$ of that obtained in oat. The amount of spores in 7 day-old colonies, developed on green pepper and oat media, was much smaller than that measured at 12 days, demonstrating that colony age could influence the amount of inoculum. 
Table 1 - Effect of culture media and light regimes on the production of spores of Colletotrichum gloeosporioides, isolated from green pepper, evaluated by counting spores in a hemocytometer, at seven and 12 days after plating. Values represents the mean of 48 replicates, obtained by readings from 6 Petri dishes (8 counts per plate).

\begin{tabular}{lcccccccc}
\hline Day & \multicolumn{4}{c}{ Culture Medium } & & \multicolumn{2}{c}{ Light Regime } \\
\cline { 2 - 3 } & & $\mathrm{Pa}$ & $\mathrm{Pm}$ & Oat & PDA & & Light & Dark \\
\hline 7 & $3.9 \mathrm{~b}$ & $2.7 \mathrm{~b}$ & $18.9 \mathrm{a}$ & $14.9 \mathrm{a}$ & & $21.1 \mathrm{a}$ & $11.7 \mathrm{a}$ \\
12 & $6.2 \mathrm{c}$ & $8.3 \mathrm{c}$ & $39.5 \mathrm{a}$ & $15.3 \mathrm{~b}$ & & $27.4 \mathrm{a}$ & $17.3 \mathrm{~b}$ \\
\hline
\end{tabular}
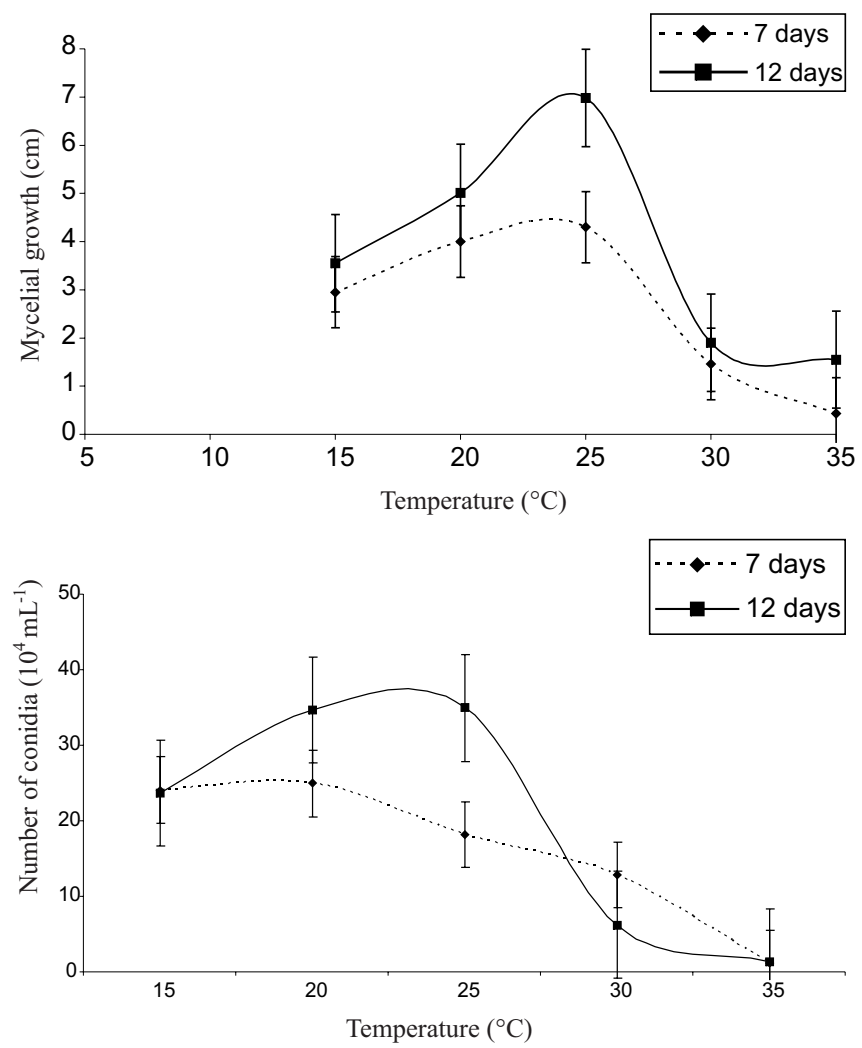

Figure 1 - Effect of incubation temperatures on the mycelial growth (A) and sporulation (B) of Colletotrichum gloeosporioides, isolated from green pepper, at 7 and 12 days after plating.

Despite containing parts or chemical substances from the fungus natural host, natural media do not always elicit the best sporulation. This behavior was also observed by Dalla Pria et al. (1997) and Hanada et al. (2002). Dalla Pria et al. (1997), in an evaluation involving three different fungi, noticed that only one of them had sporulation favored by the use of natural culture medium, while Hanada et al. (2002) observed that development of Mycosphaerella fijiensis on a medium containing leaves from banana plant, which is susceptible to the fungus, was inferior than that obtained with standard culture medium (PDA). Therefore, in addition to the require- ment for mixing host parts with the culture medium, nutritional supplements that allow increased fungi sporulation must be added.

The amount of spores produced under incubation at 20 and $25^{\circ} \mathrm{C}$ was higher than at 15,30 , and $35^{\circ} \mathrm{C}$ (Figure 1-B). A quadratic equation best fitted the dataset, and the equations for each period analyzed are:

$$
\begin{aligned}
& Y=-0.067 X^{2}+2.192 X+6.657 \quad R^{2}=0.98 \quad \text { (7 days) } \\
& Y=-0.173 X^{2}+7.216 X-43.095 R^{2}=0.81 \quad \text { (12 days) }
\end{aligned}
$$

where $\mathrm{Y}$ is the amount of spores produced and $\mathrm{X}$ is the incubation temperature.

The sporulation of fungi of the genus Colletotrichum is favored by temperatures in the range of $20-24^{\circ} \mathrm{C}$, while temperatures above $30^{\circ} \mathrm{C}$ may have an inhibitory effect (Kendrick \& Walker, 1948; Slade et al., 1987), in agreement with the results found in the present work.

Light regimes studied herein (light or dark) did not have effect on sporulation at seven days; however, at 12 days, the production of conidia was higher when incubation occurred under constant light (Table 1). In assays by Yoon \& Park (2001), the presence of light might favor spore production; in those assays, C. gloeosporioides sporulated more intensely under a regime of 16 hours of light, confirming the results found in the present work.

A recommendation can be made for culturing the fungus on oat medium, at a temperature of $25^{\circ} \mathrm{C}$, under continuous-light conditions, during 12 days, in order to obtain inoculum for experimentation purposes.

\section{REFERENCES}

DALLA PRIA, M.; BERGAMIN FILHO, A.; AMORIM, L. Avaliação de diferentes meios de cultura na esporulação de Colletotrichum lindemuthianum, Phaeosisariopsis griseola e Alternaria sp. Summa Phytopathologica, v.23, p.181-183, 1997.

HANADA, R.E.; GASPAROTTO, L.; PEREIRA, J.C.R. Esporulação de Mycosphaerella fijiensis em diferentes meios de cultura. Fitopatologia Brasileira, v.27, p.170-173, 2002.

KENDRICK, J.B.; WALKER, J.C. Anthracnose of tomato. Phytopathology, v.38, p.247-260, 1948.

KING, W.T.; MADDEN, L.V.; ELLIS, M.A.; WILSON, L.L. Effects of temperature on sporulation and latent period of Colletotrichum spp. infecting strawberry fruit. Plant Disease, v.81, p.77-84, 1997.

KUROZAWA, C.; PAVAN, M.A. Doenças das solanáceas. In: KIMATI, H.; AMORIM, L.; BERGAMIN FILHO, A.; CAMARGO, L.E.A.; REZENDE, J.A.M. Manual de fitopatologia. 3.ed. São Paulo: Agronômica Ceres, 1997. v.2, p.665-675.

SLADE, S.J.; HARRIS, R.F.; SMITH, C.S.; ANDREWS, J.H. Microcycle conidiation and spore-carrying capacity of Colletotrichum gloeosporioides on solid media. Applied and Environmental Microbiology, v.53, p.2106-2110, 1987.

YOON, J.B.; PARK, H.G. Screening method for resistance to pepper fruit anthracnose: pathogen sporulation, inoculation methods related to inoculum concentrations and post-inoculation environment. Journal of the Korean Society for Horticultural Science, v.42, p.389-393, 2001.

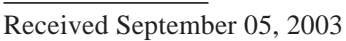

Accepted July 14, 2004 